\title{
Isolation and characterization of biosurfactants-producing bacteria isolated from palm oil industry and evaluation for biosurfactants production using low-cost substrates
}

\author{
KANOKRAT SAISA-ARD ${ }^{1}$, SUPPASIl MANEERAT ${ }^{2}$, ATIPAN SAIMMaI ${ }^{3}$ \\ ${ }^{1}$ Faculty of Science and Technology, Suratthani Rajabhat University, Suratthani, Thailand \\ ${ }^{2}$ Department of Industrial Biotechnology, Faculty of Agro-Industry, Prince of Songkla University, Hat Yai, Songkhla, Thailand \\ ${ }^{3}$ Faculty of Agricultural Technology, Phuket Rajabhat University, Phuket, Thailand \\ *Corresponding author: s4680108@hotmail.com
}

\begin{abstract}
Biosurfactants-producing bacteria were isolated from various palm oil refinery industrial sites in the south of Thailand. Isolates were screened for biosurfactant production by using low-cost, agro-industrial by-products or wastes as a substrate. Based on drop collapsing test and emulsification activity, 25 isolates were selected. All the selected isolates reduced the growth medium surface tension to $40 \mathrm{mN} / \mathrm{m}$ and produced emulsions with xylene. Twenty isolates exhibited high emulsion-stabilizing capacity, maintaining more than $50 \%$ of the original emulsion volume for $24 \mathrm{~h}$. The phylogenetic position of these 25 isolates was evaluated by $16 \mathrm{~S}$ rRNA gene sequence analysis. The production of biosurfactants was determined for strains representative of 15 different bacterial genera, six of them (Azorhizobium, Buttiauxella, Comamonas, Halopenitus, Haloplanus and Sinorhizobium) have been for the first time reported in this study as biosurfactant-producing strains. Additionally, Sinorhizobium meliloti AS91 and Marinobacter hydrocarbonoclasticus AS51 produced extracellular biosurfactant which exhibited the lowest surface tension $(32 \mathrm{mN} / \mathrm{m})$ and emulsification activity $(69 \%)$ when cashew apple juice and used vegetable oil were used as the carbon source, respectively. Overall, this is the first study of a phylogenetic analysis of biosurfactant-producing bacteria from palm oil refinery industry site and their ability to produce biosurfactant on renewable substrates.
\end{abstract}

Keywords: Isolation; biosurfactant; renewable substrate; phylogenetic analysis; palm oil contaminated soil; surface tension

\section{Introduction}

Palm oil production is a major agricultural industry in southern Thailand. The explosive expansion in the number of oil palm plantations has generated enormous amounts of waste such as solid wastes, water wastes and residual palm oil-contaminated soil or -water around industrial sites (Chavalparit et al., 2006). The microorganisms producing biosurfactants aid in their survival in the aqueous phase to adsorb, emulsify, wet and disperse or solubilize the oil or hydrophobic substrate (Nerurkar et al., 2009). The presence of biosurfactants can increase the solubility of oil and hence potentially increase their bioavailability for use as carbon and energy sources (Mulligan, 2009). Biosurfactants are amphiphilic (containing both hydrophilic and hydrophobic moieties) surface active agents produced by microorganisms. These reduce surface and interfacial tensions by accu- mulating at the interface between two immiscible fluids such as oil and water (Nitschke and Coast, 2007). Interest in biosurfactants has increased considerably in recent years as possible replacements for at least some chemical surfactants. Moreover biosurfactants can be produced from low-cost, free-cost or waste substrates from many agro-industrial processes.

However, the major concern regarding the use of biosurfactants in place of chemical surfactants is their production cost which can be kept low by selecting efficient strains of biosurfactant-producing microorganisms, thus optimizing the medium composition and using alternative inexpensive renewable substrates. The choice of low-cost, free-cost or waste substrates is important to the overall economy of the process and they account for approximately $30-50 \%$ of the final product cost and also minimize the expenses cost of waste treatment (Ruggeri 
Table 1. Identification of selected biosurfactant-producing bacterial isolates by $16 \mathrm{~S}$ rRNA gene sequence analysis

\begin{tabular}{|c|c|c|c|c|c|}
\hline \multirow{2}{*}{ No. } & \multirow{2}{*}{$\begin{array}{l}\text { Strain } \\
\text { code }\end{array}$} & \multirow{2}{*}{$\begin{array}{c}\text { GenBank } \\
\text { Accession no. }\end{array}$} & 16S rRNA gene sequence & \multirow{2}{*}{$\begin{array}{c}\text { Sequence } \\
\text { Identity } \\
(\%)\end{array}$} & \multirow{2}{*}{ Genus } \\
\hline & & & Nearest relative in GenBank & & \\
\hline 1 & AS5 & AB720125 & Bacillus tequilensis PUFSTFMId34 (KC855549) & 100 & Bacillus sp. \\
\hline 2 & AS7 & AB720127 & Bacillus safensis K-1 (KC967072) & 100 & Bacillus sp. \\
\hline 3 & AS10 & AB720130 & Bacillus licheniformis PUFSTFMPi01 (JQ677086) & 100 & Bacillus sp. \\
\hline 4 & AS12 & AB720132 & Bacillus licheniformis CRRI-HN-2 (JQ695929) & 100 & Bacillus sp. \\
\hline 5 & AS14 & AB720134 & Bacillus cereus NBRC 3003 (AB679980) & 100 & Bacillus sp. \\
\hline 6 & AS19 & AB720139 & Acinetobacter parvus LUH4616 (NR_025425) & 100 & Acinetobacter sp. \\
\hline 7 & AS22 & AB720142 & Pseudomonas aeruginosa PPI-5 (JQ773430) & 100 & Pseudomonas sp. \\
\hline 8 & AS24 & AB720144 & Pseudomonas oleovorans XA4-2 (JF496274) & 100 & Pseudomonas sp. \\
\hline 9 & AS27 & AB720147 & Pseudomonas protegens Pf-5 Pf-5 (NR_074599) & 100 & Pseudomonas sp. \\
\hline 10 & AS31 & AB720151 & Serratia marcescens SK-07 (FJ612597) & 100 & Serratia sp. \\
\hline 11 & AS34 & AB720154 & Acinetobacter junii R7-5C (HQ154562) & 100 & Acinetobacter sp. \\
\hline 12 & AS43 & $\mathrm{AB} 721286$ & Sphingobacterium spiritivorum RB91K (JQ764838) & 100 & Sphingobacterium sp. \\
\hline 13 & AS46 & AB721289 & Comamonas sp. ZJ003 (JN713433) & 100 & Comamonas sp. \\
\hline 14 & AS49 & AB721292 & Buttiauxella sp. NW51 (JF915349) & 100 & Buttiauxella sp. \\
\hline 15 & AS51 & $\mathrm{AB} 721294$ & Marinobacter hydrocarbonoclasticus KJ-W15 (JQ799112) & 100 & Marinobacter sp. \\
\hline 16 & AS89 & AB742161 & Acinetobacter gyllenbergii LUH1737 (AJ293692) & 99 & Acinetobacter sp. \\
\hline 17 & AS90 & AB742162 & Rhodococcus ruber AM (JQ819733) & 100 & Rhodococcus sp. \\
\hline 18 & AS91 & AB742163 & Sinorhizobium meliloti T2c (AB539807) & 99 & Sinorhizobium sp. \\
\hline 19 & AS92 & AB742164 & Stenotrophomonas rhizophila T2j (AB539813) & 100 & Stenotrophomonas sp. \\
\hline 20 & AS93 & AB742165 & Marinobacter pelagius KJ-W14 (JQ799111) & 100 & Marinobactersp. \\
\hline 21 & AS94 & $\mathrm{AB} 742166$ & Corynebacterium falsenii Bacteria_223 (JQ800469) & 100 & Corynebacterium sp. \\
\hline 22 & AS95 & AB742167 & Azorhizobium doebereinerae BR5401 (NR_041839) & 100 & Azorhizobium sp. \\
\hline 23 & AS96 & AB742168 & Haloplanus sp. R05-8 (EU931578) & 100 & Haloplanus sp. \\
\hline 24 & AS97 & AB742169 & Halopenitus persicus DC30 (JF979130) & 100 & Halobacteriaceae sp. \\
\hline 25 & AS117 & AB720137 & Acinetobacter calcoaceticus 97424 (HE651906) & 100 & Acinetobacter sp. \\
\hline
\end{tabular}

et al., 2009). Several recent studies have reported the screening of novel biosurfactant-producing strains from terrestrial and marine environments (Bodour et al., 2003; Bento et al., 2005; Batista et al., 2006; Toledo et al., 2006, 2008; Ruggeri et al., 2009; Saimmai et al., 2012a, 2012b, 2012c). However, few researchers have addressed the diversity of biosurfactant-producing bacteria (Bento et al., 2005; Batista et al., 2006; Ruggeri et al., 2009; Saimmai et al., 2012a, 2012c). In addition, to the best of our knowledge, this is the first report that describes the phylogenetic diversity of biosurfactant-producing bacteria from soils contaminated with palm oil in the palm oil industry. The objectives of this research were to study the microbial diversity and phylogenetic relationships of the biosurfactant-producing bacteria in soils contaminated with palm oil in the palm oil industry and evaluate the production of cost-effective substrates.

\section{Materials and methods}

\section{Isolation of biosurfactant-producing bacteria}

Biosurfactant-producing bacteria were isolated from soils contaminated with palm oil from a palm oil refinery factory in southern Thailand: 6 factory samples in Chumphon Province (CP); 10 factory samples in Krabi Pro- 
Table 2. Biosurfactant production measurement by drop collapsing test (DCT) and small-scale emulsification activity (EA) of isolates cultivated in MSM supplemented with indicated carbon source (+: positive response, -: negative response)

\begin{tabular}{|c|c|c|c|c|c|c|c|c|c|c|c|c|c|c|c|c|c|}
\hline \multirow{2}{*}{ Strain } & \multirow{2}{*}{ Sources $^{\mathrm{a}}$} & \multirow{2}{*}{$\begin{array}{l}\text { Gram } \\
\text { stain }^{b}\end{array}$} & \multicolumn{13}{|c|}{ Growth $^{\mathrm{c}}$} & \multirow{2}{*}{$\mathrm{DCT}^{\mathrm{d}}$} & \multirow{2}{*}{$\mathrm{EA}^{\mathrm{c}}$} \\
\hline & & & $\mathrm{BP}^{\mathrm{a}}$ & $\mathrm{CAJ}$ & $\mathrm{CS}$ & CG & $\mathrm{CPO}$ & GL & MO & PODC & POME & TLD & ULO & UPO & UVO & & \\
\hline AS5 & $\mathrm{CP}$ & $\mathrm{P}$ & + & + & + & + & + & - & + & + & + & - & + & + & + & + & + \\
\hline AS7 & $\mathrm{CP}$ & $\mathrm{P}$ & + & + & + & + & + & + & + & + & + & + & - & + & + & + & + \\
\hline AS10 & $\mathrm{CP}$ & $\mathrm{P}$ & + & + & + & - & + & + & + & + & + & + & - & + & + & + & + \\
\hline AS12 & $\mathrm{KP}$ & $\mathrm{P}$ & + & + & - & - & + & + & - & + & + & - & - & + & + & + & + \\
\hline AS14 & $\mathrm{KP}$ & $\mathrm{P}$ & + & + & + & - & + & + & + & + & + & + & - & + & + & + & + \\
\hline AS19 & $\mathrm{KP}$ & $\mathrm{N}$ & + & + & + & - & + & + & + & + & + & + & - & + & + & + & + \\
\hline AS22 & $\mathrm{KP}$ & $\mathrm{N}$ & + & - & + & - & + & + & + & + & + & + & - & + & + & + & + \\
\hline AS24 & $\mathrm{KP}$ & $\mathrm{N}$ & + & + & + & - & + & + & + & + & + & + & - & + & + & + & + \\
\hline AS27 & $\mathrm{KP}$ & $\mathrm{N}$ & + & + & + & - & + & + & + & + & + & + & + & + & + & + & + \\
\hline AS31 & $\mathrm{KP}$ & $\mathrm{N}$ & + & + & + & - & + & + & + & + & + & + & + & - & - & + & + \\
\hline AS34 & $\mathrm{SP}$ & $\mathrm{N}$ & + & + & + & + & + & + & + & - & + & + & - & + & + & + & + \\
\hline AS43 & $\mathrm{SP}$ & $\mathrm{N}$ & + & + & + & - & + & + & + & + & + & + & - & + & + & + & + \\
\hline AS46 & $\mathrm{SA}$ & $\mathrm{N}$ & + & + & + & - & + & + & + & + & + & + & - & + & + & + & + \\
\hline AS49 & $\mathrm{SA}$ & $\mathrm{N}$ & + & + & + & - & + & + & + & + & + & + & - & + & + & + & + \\
\hline AS51 & $\mathrm{SA}$ & $\mathrm{N}$ & + & + & + & - & + & + & + & + & + & + & - & + & + & + & + \\
\hline AS89 & $\mathrm{SU}$ & $\mathrm{N}$ & + & + & + & - & + & + & + & + & + & + & - & + & + & + & + \\
\hline AS90 & SU & $\mathrm{P}$ & + & + & + & - & + & + & + & + & + & + & + & + & + & + & + \\
\hline AS91 & $\mathrm{SU}$ & $\mathrm{N}$ & + & + & + & - & + & + & + & + & + & + & - & - & - & + & + \\
\hline AS92 & SU & $\mathrm{N}$ & + & + & + & - & + & + & + & + & + & + & - & + & + & + & + \\
\hline AS93 & $\mathrm{SU}$ & $\mathrm{N}$ & + & + & + & - & +- & + & + & - & + & + & - & + & + & + & + \\
\hline AS94 & $\mathrm{SU}$ & $\mathrm{P}$ & + & + & + & - & + & + & + & + & + & + & - & + & + & + & + \\
\hline AS95 & $\mathrm{TP}$ & $\mathrm{N}$ & + & + & + & - & + & + & + & + & + & - & + & + & + & + & + \\
\hline AS96 & $\mathrm{TP}$ & $\mathrm{N}$ & + & + & + & - & + & + & + & + & + & + & - & - & - & + & + \\
\hline AS97 & $\mathrm{TP}$ & $\mathrm{N}$ & + & + & + & + & + & + & - & - & + & + & - & + & + & + & + \\
\hline AS117 & $\mathrm{TP}$ & $\mathrm{N}$ & - & + & + & + & + & + & + & + & + & + & - & - & - & + & - \\
\hline
\end{tabular}

${ }^{\mathrm{a}}$ See text for details of sampling locations and type of carbon sources; ${ }^{\mathrm{b}}$ Gram stain: $\mathrm{P}-$ Gram positive; $\mathrm{N}-\mathrm{Gram}$ negative; ${ }^{\mathrm{c}}+$ biomass increase more than tenfold compared to the inoculum; - non-growth; ${ }^{\mathrm{d}}+$ positive test at least with one carbon source; - negative test with the five tested carbon sources

vince (KP); 2 factory samples in Satun Province (SA); 1 factory samples in Songkhla Province (SP); 13 factory samples in Surathani Province (SU); and 3 factory samples in Trang Province (TP). The samples were collected in plastic zipper bags and transported to the laboratory for screening and isolation. Screening was performed using serial dilutions of the samples and plating on a minimal salt medium (MSM) (Saimmai et al., 2012a). MSM agar, with used palm oil (UPO; 1\%, w/v) as the carbon source, was used for the isolation of bacteria. Morphologically distinct colonies were re-isolated by transferring them onto fresh UPO-containing agar plates at least three times, to obtain pure cultures, and were subsequently Gram stained (Holt et al., 1994). Pure cultures were stored at $-20^{\circ} \mathrm{C}$ in MSM mixed with sterile glycerol at a final concentration of $30 \%$.

\section{Screening of biosurfactant-producing bacteria}

One loop of each isolate was transferred to test tubes containing $5 \mathrm{ml}$ of nutrient broth (NB, Difco, MI, USA) and shaken $(1.45 \times g)$ at $30^{\circ} \mathrm{C}$ for $18-24 \mathrm{~h}$. Cell suspensions were adjusted to an optical density (OD) of 0.10 \pm 0.05 at $600 \mathrm{~nm}$, and $100 \mu \mathrm{l}$ of cell culture was transferred to $5 \mathrm{ml}$ of MSM supplemented with $1 \%(\mathrm{w} / \mathrm{v})$ of diffe 
rent carbon

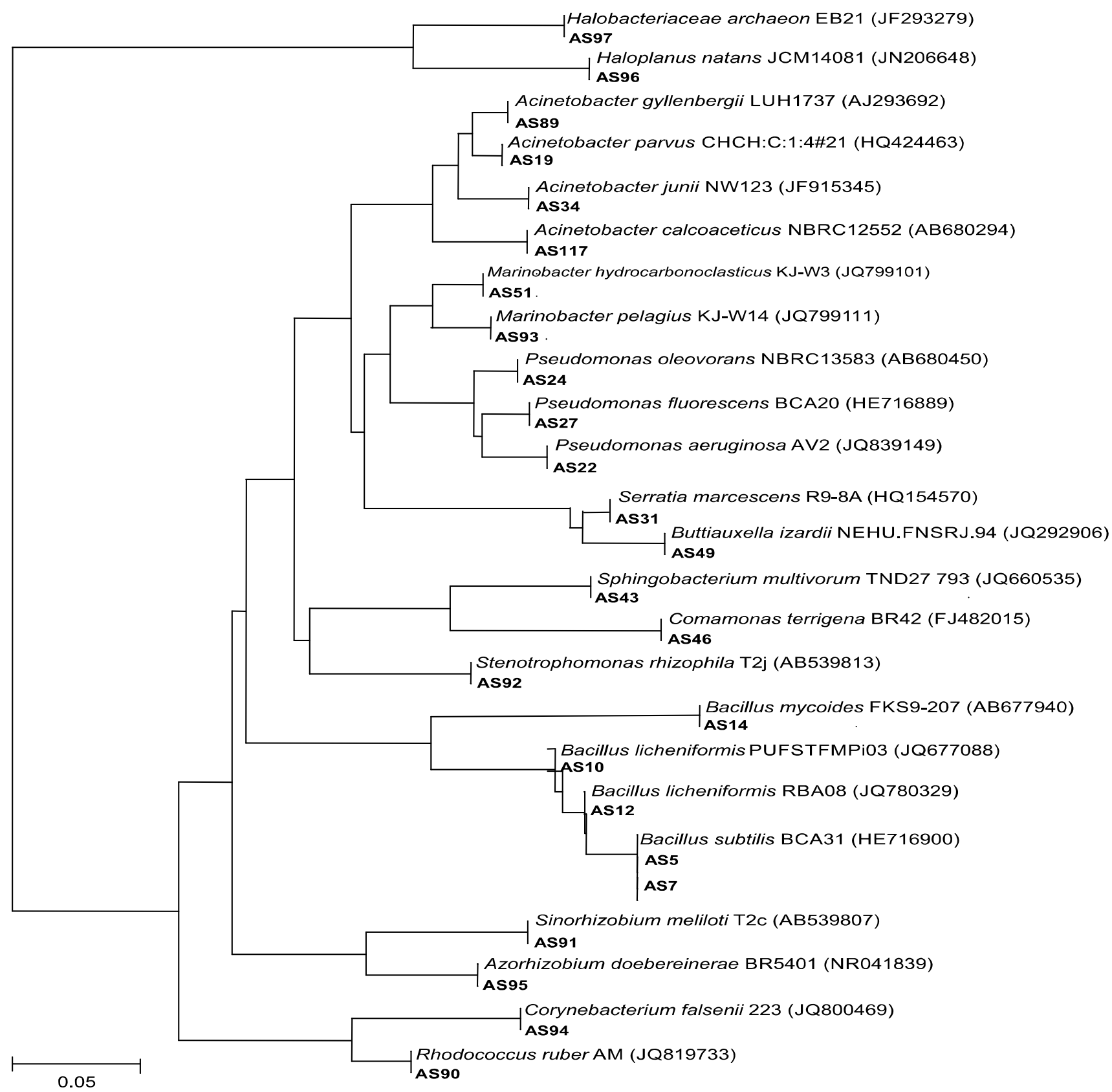

Fig. 1. Unrooted phylogenetic tree based on $16 \mathrm{~S}$ rRNA gene comparison of the biosurfactants-producing bacteria isolated from soils contaminated with palm oil from the palm oil industry shown in this study (bold) and the nearest relative in GenBank. Bootstrap probability values of $<50 \%$ were omitted from the figure. Scale bar indicates substitutions per nucleotide position.

GenBank accession numbers are given in parenthesis

sources. The following were placed in a rotary shaker (Vision Scientific, Daejon, Korea) at $30^{\circ} \mathrm{C}$ and $2.23 \times g$ for seven days: banana peel (BP); cashew apple juice (CAJ); commercial sugar (CS); crude glycerol (CG); crude palm oil (CPO); glucose (GL); molasses (MO); palm oil decan- ter cake (PODC); palm oil mill effluent (POME); traditional liquor distillation (TLD); used lubricating oil (ULO); used palm oil (UPO); or used vegetable oil (UVO). Screening for biosurfactant-producing bacterial isolates was performed using a drop collapsing test (Youssef et al., 
2004) and the small-scale activity test (Plaza et al., 2006; Ruggeri et al., 2009) of the culture supernatant after centrifugation at $9.700 \times g$ at $4{ }^{\circ} \mathrm{C}$ for $10 \mathrm{~min}$.

\section{Identification of bacterial isolates}

Selected isolates were incubated for $48 \mathrm{~h}$ at $30^{\circ} \mathrm{C}$ on MSM agar supplemented with $1 \%$ (w/v) of ULO or GL and subsequently Gram stained. For 16S rRNA gene amplification, selected bacterial isolate chromosomal DNA was isolated using a Roche kit (Roche Applied Science, Mannheim, Germany) following the manufacture's instruction. The 16S rRNA gene was amplified using the PCR method with a 1U Taq DNA polymerase (Bio-Lab Ltd., Auckland, New Zealand) and universal bacterial primers 8F (5'-AGAGTTTG ATCCTGGCTCAG-3') and 1492R (5'-GGTTACCTTGTTACGACTT-3') (Turner et al., 1999). The following PCR conditions were used: $95^{\circ} \mathrm{C}$ for $5 \mathrm{~min}$, followed by 25 cycles of $95^{\circ} \mathrm{C}$ for $1 \mathrm{~min}, 50^{\circ} \mathrm{C}$ for $30 \mathrm{~s}$, and $72^{\circ} \mathrm{C}$ for $1.5 \mathrm{~min}$, followed by $72^{\circ} \mathrm{C}$ for $5 \mathrm{~min}$. Then, the DNA fingerprints were electrophoresed for $24 \mathrm{~min}$ at $100 \mathrm{~V}$ on $1 \%$ TAE agarose gel. The gel was visualized with ethidium bromide under UV light. The PCR product was purified using the QiAmp PCR purification kit (QIAGEN, Inc.) following the manufacturer's instruction. The purified PCR was electrophoresed on a $1 \%$ TAE agarose gel for $24 \mathrm{~min}$ at 100 Volts. The $16 \mathrm{~S}$ rRNA gene sequences obtained were aligned with the sequences of type strains obtained from GenBank by using the program ClustalW (Thompson et al., 1997). Sequence homologies were examined using BLAST version 2.2.12 of the National Center for Biotechnology Information and a consensus neighbor-joining tree was constructed using Molecular Evolutionary Genetics Analysis (MEGA) Software Version 4.0 (Tamura et al., 2007). The 16S rRNA gene sequences were submitted to GenBank with accession numbers as shown in Table 1.

\section{Evaluation of biosurfactant production}

Twenty-five selected isolates were evaluated for the biosurfactant production in $250 \mathrm{ml}$ Erlenmeyer flasks containing $50 \mathrm{ml}$ of MSM with 1\% (w/v) of the selected carbon sources mentioned in Materials and methods section. The isolates were activated by growing them in $\mathrm{NB}$ and shaken $(1.45 \times g)$ at $30^{\circ} \mathrm{C}$ for $18-24 \mathrm{~h}$. Cell suspensions were diluted to $\mathrm{OD}_{600}$ of 0.10 , and $5 \mathrm{ml}$ of these suspensions were used as starters. Culture flasks were incubated at $30^{\circ} \mathrm{C}$ with continuous shaking at $2.23 \times g$ for
7 days. Cell growth was monitored at $600 \mathrm{~nm}$ (spectrophotometer Libra S22, Biochrom Ltd., Cambridge, England). Biosurfactant emulsification activities (EA) of the culture supernatants, after centrifugation $(9.700 \times g$ at $4^{\circ} \mathrm{C}$ for $10 \mathrm{~min}$ ), were measured as changes in surface tension by the duNouy method (Jachimska et al., 1995) using a ring tensiometer (OS, Torsion Balance, Warwickshire, UK). The activity of synthetic surfactants SDS (Sigma Chemicals Ltd., Missouri, USA) and Tween 80 (Sigma Chemicals Ltd., Missouri, USA) (10 g/l) were tested at concentrations higher than their critical micelle concentrations $(2.0 \mathrm{~g} / 1$ and $0.16 \mathrm{~g} / \mathrm{l}$, respectively). MSM medium supplemented with different carbon sources without inoculums was used as a negative control.

\section{Results and discussion}

\section{Isolation and screening of biosurfactant-producing bacteria}

A total of 864 bacterial isolates were isolated including 125 isolates from $\mathrm{CP}, 287$ isolates from $\mathrm{KP}, 81$ isolates from SA, 41 isolates from SP, 251 isolates from SU and 79 isolates from TP. Seventy-five percent of the bacterial isolates (648 of 864) were Gram negative (data not shown). It has previously been reported that most bacteria isolated from hydrocarbon- or oil-contaminated environments are Gram negative (Bicca et al., 1999; Bodour et al., 2003; Batista et al., 2006; Saimmai et al., 2012a, 2012c). This may be the characteristic that contributes to the majority of the populations surviving such stressful conditions (Bicca et al., 1999).

Biosurfactants can only be considered as substitutes of synthetic surfactants if the cost of the raw material and the process is minimal. The use of alternative substrates such as agro-based industrial wastes is one of the attractive strategies for economical biosurfactants production and use of different substrates also result in distinct chemical structure, composition and physical properties of the obtained biosurfactants (Makkar and Cameotra, 2002). Therefore, unconventional carbon sources, such as BP, CAJ, PODC, POME and TLD were applied as the carbon sources for biosurfactant production in this research. Among the carbon sources tested, CPO and POME were the best carbon sources for growth and biosurfactant production from selected isolates. Twentyfive isolates were positive for biosurfactant production in at least one of tested methods after $48 \mathrm{~h}$ of cultivation 
when they were used as a carbon source. CPO and POME are one of the most important potential feed stocks, available in large quantities from the palm oil refinery factories found in southern Thailand.

\section{Identification, taxonomy and phylogeny of the biosurfactant-producing bacteria}

All of the isolates present in this study were chemoheterotrophs with 7 Gram positive and 18 Gram negative. The morphology of cells and colonies as well as their biochemical and physiological characteristics were tested (data not shown). Due to intrinsic limitations, the biochemical and physiological features can only provide preliminarily identification (Bizet et al., 1997). The final identification of strains was accomplished by combining the alignment results of 16S rRNA sequence analysis with biochemical and physiological characteristics. Their sequences were assigned with the NCBI database and deposited in DDBJ/EMBL/GenBank with the accession numbers (Table 1). All sequences were included for phylogenetic analysis, and separated into 15 different phylotypes based on 16S rRNA sequence analysis (Fig. 1). The phylogenetic analysis of biosurfactants-producing bacteria isolated from soil contaminated with palm oil from the palm oil industry revealed that it contained representatives from the following bacterial divisions: Archaea, High GC Actinobacteria, Low GC Gram positives (Firmicutes), microaerobic of Bacteroidetes and with Proteobacteria with the largest fraction of detected phylotypes (15 species).

Five isolate sequences were related to the $16 \mathrm{~S}$ rRNA genes of members of the genus Bacillus with the sequences identity values of $100 \%$ (Table 1 ). In addition, isolate AS10 and AS12 were almost identical to the 16S rRNA of $B$. licheniformis, the other isolates of AS5, AS7 and AS14 were $B$. tequilensis, $B$. safensis and $B$. cereus, respectively. Four isolates of Proteobacteria (AS19, AS34, AS89 and AS117) could be assigned to the 16S rRNAencoding genes of the genus Acinetobacter. Isolates AS22, AS24, and AS27 were assigned to the 16S rRNA of representatives of the genus Pseudomonas with sequence identities of $100 \%$. With sequence identities of $100 \%$, isolates AS31, AS90 and AS94 were similar to the genus Serratia, Rhodococcus and Corynebacterium, respectively.

Acinetobacter, Bacillus, Corynebacterium, Pseudomonas, Rhodococcus and Serratia are the common genera for biosurfactant-producing bacteria which are nor- mally isolated from hydrophobic substrate contaminated samples either from terrestrials or marine sites (Batista et al., 2006; Ruggeri et al., 2009; Das et al., 2010; Saimmai et al., 2012a, 2012c). These genera have also been described as being more efficient hydrocarbon-degrading bacteria (Yakimov et al., 2007). Two of the isolates (AS51 and AS93) related to the $16 \mathrm{~S}$ rRNA sequences of the genus Marinobacter (similar to $M$. hydrocarbonoclasticus and M. Pelagius with sequence identities of $100 \%$, respectively). Marinobacter spp. are reported to degrade hydrocarbons (aliphatic, aromatic and naphthalene) (Brito et al., 2006; Yakimov et al., 2007). M. hydrocarbonoclasticus SP17 also produces surface active compounds when using hexadecane as a sole carbon source (Klein et al., 2010).

The remaining 8 isolates, AS43; AS46; AS49; AS91; AS92; AS95; AS96 and AS97 were similar to the genus Sphingobacterium, Comamonas, Buttiauxella, Sinorhizobium, Stenotrophomonas, Azorhizobium, Haloplanus and Halopenitus with sequence identities of $100 \%$, respectively (Table 1). The genus Sphingobacterium and Stenotrophomonas has already been described as an effective biosurfactant-producing strain which reduces surface tension of culture supernatant to 27.8 and $32 \mathrm{mN} / \mathrm{m}$ in $30 \mathrm{~h}$ of cultivation (Burgos-Díaz et al., 2011; Patil et al., 2012). However, the high EA and very poor in surface tension reduction of $S$. spiritivorum AS43 (59.52\%, $4.0 \mathrm{mN} / \mathrm{m})$ and $S$. rhizophila AS92 $(66.23 \%, 3.0 \mathrm{mN} / \mathrm{m})$ (Table 1) in the present study indicate that they were high-molecular-weight biosurfactants or bioemulsifiers rather than low-molecular-weight biosurfactants.

To the best of our knowledge, this is the first study that describes the following six genera to the list of biosurfactant-producing bacteria: Azorhizobium; Buttiauxella; Comamonas; Halopenitus; Haloplanus, and Sinorhizobium. The genera of Azorhizobium, Comamonas, Halopenitus, and Sinorhizobium have already been described as extracellular polymeric substances (EPSs) or biofilm (Bahlawane et al., 2008; Poli et al., 2011) producing genera. However, no reports can be found on the biosurfactant production capability of these genera. EPSs are important in microbial interaction and emulsification of various hydrophobic substrates (Satpute et al., 2010). They are known to increase the viscosity of solutions at low $\mathrm{pH}$ and emulsify several hydrocarbon compounds. These phenomena can enhance the bioavailability of hydrophobic compounds, and make them available as substrates for microbial growth and metabolite 
production (Perfumo et al., 2010). Finding 15 different bacterial genera in palm oil refinery industrial sites indicates that there is a wide biodiversity of biosurfactantproducing bacteria in soils contaminated with palm oil.

\section{Evaluate biosurfactant production on low-cost fermentative medium}

Carbon source plays a key role in biosurfactant production by selected bacterial isolates. All of the selected isolates could produce biosurfactant and gave positive results with small-scale EA or drop collapsing. In general, the carbon source used in bacterial culture can be divided into two categories: water-insoluble carbon sources and water-soluble carbon sources. Water-insoluble carbon sources such as vegetable oil or hydrocarbon compounds are widely used for biosurfactant production (Banat et al., 2010). In the present study, when waterinsoluble carbon sources, including CPO, UPO and UVO were used, all tested isolates showed growth. It was found that 20 isolates produced stable oil-culture supernatant emulsion and 21 isolates reduced surface tension of culture supernatant (Table 2). Out of these isolates, M. hydrocarbonoclasticus AS51 possess the highest EA (E24) and lowest surface tension reduction with $69 \%$ and $36 \mathrm{mN} / \mathrm{m}$ when UVO was used as a sole carbon source (supplementary Table 1).

Among the tested water-insoluble carbon sources, UVO was found to be a prominent carbon sources for biosurfactant production (Table 1). The world production of vegetable oils is about 2.5-3 million tons/years, $75 \%$ of which are derived from plants (Haba et al., 2000). Most of these oils are used in the food industry, especially for frying processes, and generate great quantities of by-products and wastes. The use of economic substrates such as hydrophobic wastes meets one of the requirements to reduce the cost of biosurfactant production.

All of the 25 selected isolates could grow on various tested soluble carbon sources and 18 isolates were positive for biosurfactant production by using soluble carbon sources as a substrate (Table 2). Among them, Sinorhizobium meliloti AS91 produced biosurfactant with the lowest surfactant tension $(32 \mathrm{mN} / \mathrm{m})$ when CAJ was used as a carbon source (supplementary Table 1). Cashew apple (Anarcardium occidentale L.) is a pseudo-fruit rich in reducing sugars (fructose and glucose), vitamins, minerals and some amino acids (Honorato et al., 2007). The cashew tree grows in quite large areas even on poor soils with low precipitation rate and is cultivated in 32 countries around the world. Brazil, India, Vietnam, Nigeria and Thailand are its main producers. Although cashew apples can be consumed as juice, ice cream and other edible products, cashew tree cultivation is an agricultural practice that aims mainly at the production of cashew nuts. The nuts represent only $10 \%$ of the total fruit weight, and large amounts of cashew apples are left in the field after the nuts are harvested (Neelakandan and Usharani, 2009). These facts, together with its rich nutrient composition (e.g., carbohydrate, fibers, vitamins and minerals salts), make CAJ an interesting and inexpensive culture medium for biosurfactant production.

Among 25 selected isolates evaluated for biosurfactant production in flasks by using soluble carbon sources as a substrate, Serratia marcescens AS31 showed the highest EA (67\%) when BP was used as a carbon source (supplementary Table 1). Banana is one of the most abundantly available fruits in tropical countries. World production of banana is estimated at 48.9 million tons. The main by-product of the banana processing industry is the peel, which represents approximately $30 \%$ of the fruit. This by-product poses an environmental problem because it contains large quantities of nitrogen and phosphorus and its high water content makes it susceptible to modification by microorganisms. The potential applications for banana peel depend on its chemical composition. Banana peel is rich in dietary fiber (50\% on a dry matter (DW) basis), proteins (7\% DW), essential amino acids, polyunsaturated fatty acids and potassium (Emaga et al., 2007). Attempts at the practical utilization of banana by-products include the production of citric acid (Karthikeyan and Sivakumar, 2010), pectin (Emaga et al., 2008) and ethanol (Arredondo et al., 2009), as well as production of biomass and metabolites of biotechnological interest (Kokab et al., 2003; Essien et al., 2005; Osma et al., 2007). Banana peel has also been used as bioadsorbent of soluble contaminants, such as dyes (Hossain et al., 2012), metals (Memon et al., 2009), and phenolic compounds (Achak et al., 2009). However, there are no reports describing banana peel for biosurfactant production so far.

To date, biosurfactants are unable to compete with chemical surfactants in terms of economics due to their low yield and higher production expenditures. However, the selection of high-yield strains and the use of costeffective substrates like industrial and domestic wastes, 
provide an appropriate balance in the nutrient contents required for the microbial population. In the present study, diversity of biosurfactant-producing bacteria isolated from soil contaminated with palm oil from the palm oil industry was studied and biosurfactant production from agro-industrial by-products or wastes was evaluated. The use of cheap raw materials and wastes will contribute to the reduction of production costs. Consequently, the potential applications of biosurfactants on a commercial scale should be encouraged. In addition, our data points towards the evaluation of potential applications of biosurfactants produced by novel strains.

\section{Acknowledgements}

We are grateful to Phuket Rajabhat University for providing a scholarship to Saimmai A. This work was supported by the Higher Education Research Promotion and National Research University Project of Thailand, Office of the Higher Education Commission and International Foundation for Science (Sweden) No. F/5204-1.

\section{References}

Achak M., Hafidi A., Ouazzani N., Sayadi S., Mandi L. (2009) Low cost biosorbent "banana peel" for the removal of phenolic compounds from olive mill wastewater: kinetic and equilibrium studies. J. Hazard. Mat. 166: 117-125.

Arredondo H.I.V., Colorado R.A., Oliveira S. (2009) Ethanol production from banana fruit and its lignocellulosic residues: energy and renewability analysis. Int. J. Thermody. 12: $155-162$.

Bahlawane C., McIntosh M., Krol E., Becker A. (2008) Sinorhizobium meliloti regulator MucR couples exopolysaccharide synthesis and motility. Mol. Plant. Microbe. Interact. 21: 1498-1509.

Banat I.M., Franzetti A., Gandolfi I., Bestetti G., Martinotti M.G., Fracchia L., Smyth T.J., Marchant R. (2010) Microbial biosurfactants production, applications and future potential. Appl. Microbiol. Biotechnol. 87: 427-444.

Batista S.B., Mounteer A.H., Amorim F.R., Totola M.R. (2006) Isolation and characterization of biosurfactant/bioemulsifierproducing bacteria from petroleum contaminated sites. Bioresource Technol. 97: 868-875.

Bento F.M., Camargo F.A., Okeke B.C., Frankenberger W.T. (2005) Diversity of biosurfactant producing microorganisms isolated from soils contaminated with diesel oil. Microbiol. Res. 160: 249-255.

Bicca F.C., Fleck L.C., Ayub M.A.Z. (1999) Production of biosurfactant by hydrocarbon degrading Rhodococcus ruber and Rhodococcus erythropolis. Rev. Microbiol. 30: 231-236.

Bizet C., Barreau C., Harmant C., Nowakowski M., Pietfroid A. (1997) Identification of Rhodococcus, Gordona and Dietzia species using carbon source utilization tests (“Biotype-100" strips). Res. Microbiol. 148: 799-809.
Bodour A.A., Drees K.P., Raina M.M. (2003) Distribution of biosurfactant-producing bacteria in undisturbed and contaminated arid southwestern soils. Appl. Environ. Microbiol. 69: 3280-3287.

Bossier P., Verstraete W. (1996) Comamonas testosteroni colony phenotype influences exopolysaccharide production and coaggregation with yeast cells. Appl. Environ. Microbiol. 62: 2687-2691.

Bouffartigues E., Gicquel G., Bazire A., Fito-Boncompte L., Taupin L., Maillot O., Groboillot, A., Poc-Duclairoir C., Orange N., Feuilloley M., Dufour A., Chevalier, S. (2011) The major outer membrane protein OprF is required for rhamnolipid production in Pseudomonas aeruginosa. J. Bacteriol. Parasitol. 2: 118.

Brito E.M.S., Guyoneaud R.M., Gońi-Urriza M., RanchouPeyruse A., Verbaere A., Crapez M.A.C., Wasserman J.C.S.A., Duran R. (2006) Characterization of hydrocarbonoclastic bacterial communities from mangrove sediments in Guanabara bay. Braz. Res. Microbiol. 157: 752-762.

Burgos-Díaz C., Pons R., Espuny M.J., Aranda F.J., Teruel J.A., Manresa A., Ortiz A., Marqués A.M. (2011) Isolation and partial characterization of a biosurfactant mixture produced by Sphingobacterium sp. isolated from soil. J. Colloid. Interface. Sci. 361: 195-204.

Chavalparit O., Rulkens W.H., Mol A.P.J., Khaodhair S. (2006) Options for environmental sustainability of the crude palm oil industry in Thailand through enhancement of industrial ecosystems. Environ. Dev. Sustain. 8: 271-287.

Chonga M.L., Rahima R.A., Shiraib Y., Hassana M.A. (2009) Biohydrogen production by Clostridium butyricum EB6 from palm oil mill effluent. Int. J. Hydrogen. Energ. 34: 764-771.

D’Haeze W., Glushka J., De Rycke R., Holsters M., Carlson R.W. (2004) Structural characterization of extracellular polysaccharides of Azorhizobium caulinodans and importance for nodule initiation on Sesbania rostrata. Mol. Microbiol. 52: 485-500.

Das P., Mukherjee S., Sivapathasekaran S., Sen R. (2010) Microbial surfactants of marine origin: potentials and prospects. Adv. Exp. Med. Biol. 672: 88-101.

Emaga T.H., Andrianaivo R.H., Wathelet B., Tchango J.T., Paquot M. (2007) Effects of the stage of maturation and varieties on the chemical composition of banana and plantain peels. Food Chem. 103: 590-600.

Emaga T.H., Ronkart S.N., Robert C., Wathelet B., Paquot M. (2008) Characterisation of pectins extracted from banana peels (Musa Aaa) under different conditions using an experimental design. Food Chem. 108: 463-471.

Essien J.P., Akpan E.J., Essien E.P. (2005) Studies on mould growth and biomass production using waste banana peel. Bioresource Technol. 96: 1451-1456.

Franzetti A., Gandolfi I., Bertolini V., Raimondi C., Piscitello M. (2011) Phylogenetic characterization of bioemulsifierproducing bacteria. Int. Biodeter. Biodegr. 65: 1095-1099.

Guerin T.F. (2002) Heavy equipment maintenance wastes and environmental management in the mining industry. J. Environ. Manage. 66: 185-199. 
Haba E., Espuny M.J., Busquets M., Manresa A. (2000) Screening and production of rhamnolipids by Pseudomonas aeruginosa 47T2 NCIB 40044 from waste frying oils. J. Appl. Microbiol. 88: 379387.

Holt J.G., Kreig N.R., Sneath P.H.A., Stanley J.T., William S.T. (1994) Bergey's manual determinative bacteriology. William and Wilkins, Baltimore.

Honorato T.L., Rabelo M.C., Goncalves L.R.B., Pinto C.A.S., Rodrigues S. (2007) Fermentation of cashew apple juice to produce high added value products. World. J. Microbiol. Biotechnol. 23: 1409-1415.

Hossain M.A., Ngo H.H., Guo W.S., Nguyen T.V. (2012) Biosorption of $\mathrm{Cu}$ (II) from water by banana peel based biosorbent: experiments and models of adsorption and desorption. J. Water Sustain. 2: 87-104.

Jachimska B., Lunkenheimer K., Malysa K. (1995) Effect of position of the functional group on the equilibrium and surfa ce properties of butyl alcohols. J. Colloid. Interf. Sci. 176: 31-38.

Karthikeyan A., Sivakumar N. (2010) Citric acid production by koji fermentation using banana peel as a novel substrate. Bioresource Technol. 101: 5552-5556.

Klein B., Bouriat P., Goulas P., Grimaud R. (2010) Behavior of Marinobacter hydrocarbonoclasticus SP17 cells during initiation of biofilm formation at the alkane-water interface. Biotechnol. Bioeng. 105: 461-468.

Kokab S., Asghar M., Rehman K., Asad M.J., Adedyo O. (2003) Bio-processing of banana peel for $\alpha$-amylase production by Bacillus subtilis. Int. J. Agricul. Biol. 5: 36-39.

Li J.L., Chen B.H. (2009) Surfactant-mediated biodegradation of polycyclic aromatic hydrocarbons. Mater. 2: 76-94.

Ma A.N. (2000) Environmental management for the palm oil industry. Palm. Oil. Dev. 30: 1-9.

Makkar R.S., Cameotra S.S. (2002) An update on the use of unconventional substrates for biosurfactant production and their new application. Appl. Microbiol. Biotechnol. 58: 428-434.

Memon J.R., Memon S.Q., Bhanger M.I., El-Turki A., Hallam K.R., Allen G.C. (2009) Banana peel: a green and economical sorbent for the selective removal of $\mathrm{Cr}(\mathrm{VI})$ from industrial wastewater. Colloid. Surf. B. 70: 232-237.

Mulligan C.N. (2009) Recent advances in the environmental applications of biosurfactants. Curr. Opin. Colloid In. 14: 372-378.

Nawawi W.M.F.W., Jamal P., Alam M.Z. (2010) Utilization of sludge palm oil as a novel substrate for biosurfactant production. Bioresource Technol. 101: 9241-9247.

Neelakandan T., Usharani G. (2009) Optimization and production of bioethanol from cashew apple juice using immobilized yeast cells by Saccaharomyces cerevisiae. Am-Eur. J. Scic. Res. 4: 85-88.

Nerurkar A.S., Hingurao K.S., Suthar H.G. (2009) Bioemulsifiers from marine microorganisms. J. Sci. Ind. Res. 68: 273-277.

Ng W.K., Wang Y. (2011) Inclusion of crude palm oil in the brood stock diets of female Nile tilapia, Oreochromis nilo- ticus, resulted in enhanced reproductive performance compared to brood fish fed diets with added fish oil or linseed oil. Aquaculture. 314: 122-131.

Nitschke M., Coast S.G. (2007) Biosurfactants in food industry. Trends Food Sci. Technol. 18: 252-259.

Osma J.F., Herrera J.L.T., Couto S.R. (2007) Banana skin: a novel waste for laccase production by trametes pubescens under solid-state conditions. application to synthetic dye decolouration. Dyes Pigments. 75: 32-37.

Patil S.N., Aglave B.A., Pethkar A.V., Gaikwad V.B. (2012) Stenotrophomonas koreensis a novel biosurfactant producer for abatement of heavy metals from the environment. Afr. J. Microbiol. Res. 6: 5173-5178.

Perfumo A., Smyth T.J.P., Marchant R., Banat I.M. (2010) Production and roles of biosurfactants and bioemulsifiers in accessing hydrophobic substrates. In: Timmis KN, editor. Handbook of hydrocarbon and lipid microbiology. Springer-Verlag, Berlin, Germany. p. 1501-1512.

Plaza G.A., Zjawiony I., Banat I.M. (2006) Use of different methods for detection of thermophilic biosurfactant-producing bacteria from hydrocarbon contaminated and bioremediated soils. J. Pet. Sci. Eng. 50: 71-77.

Poli A., Donato P.D., Abbamondi G.R., Nicolaus B. (2011) Synthesis, production, and biotechnological applications of exopolysaccharides and polyhydroxyalkanoates by archaea. Archaea. doi:10.1155: 693-253.

Ruggeri C., Franzetti A., Bestetti G., Caredda P., La Colla P., Pintus M., Sergi S., Tamburini E. (2009) Isolation and characterization of surface active compound-producing bacteria from hydrocarbon-contaminated environments. Int. Biodeter. Biodegr. 63: 936-942.

Saimmai A., Rukadee O., Onlamool T., Sobhon V., Maneerat S. (2012a) Characterization and phylogenetic analysis of microbial surface active compounds-producing bacteria. Appl. Biochem. Biotech. 168: 1003-1018.

Saimmai A., Sobhon V., Maneerat S. (2012b) Production of biosurfactant from a new and promising strain of Leucobacter komagatae 183. Ann. Microbiol. 62: 391-402.

Saimmai A., Tani A., Sobhon V., Maneerat S. (2012c) Mangrove sediment, a new source of potential biosurfactant producing bacteria. Ann. Microbiol. 62: 1669-1679.

Satpute S.K., Banat I.M., Dhakephalkar P.K., Banpurkar A.G., Chopade B.A. (2010) Biosurfactants, bioemulsifiers and exopolysaccharides from marine microorganisms. Biotechnol. Adv. 28: 436-450.

Tamura K., Dudley J., Nei M., Kumar S. (2007) MEGA4: Molecular evolutionary genetics analysis (MEGA) software version 4.0. Mol. Biol. Evol. 24: 1596-1599.

Thompson J.D., Gibbons T.J., Plewniak F., Jeanmougin F., Higgins D.G. (1997) The CLUSTAL $X$ windows interfac: flexible strategies for multiple sequence alignment aided by quality analysis tools. Nucleic Acids Res. 25: 4876-4882.

Toledo F.L., Calvo C., Rodelas B., Gonzalez-Lopez J. (2006) Selection and identification of bacteria isolated from waste crude oil with polycyclic aromatic hydrocarbons removal capacities. Syst. Appl. Microbiol. 29: 244-252. 
Toledo F.L., Gonzalez-Lopez J., Calvo C. (2008) Production of bioemulsifier by Bacillus subtilis, Alcaligenes faecalis and Enterobacter species in liquid culture, Bioresource Technol. 99: 8470-8475.

Turner S., Pryer K.M., Miao V.P.W., Palmer J.D. (1999) Investigating deep phylogenetic relationships among cyanobacteria and plastids by small subunit $r R N A$ sequence analysis. J. Eukaryot. Microbiol. 46: 327-338.

Wong Y.M., Brigham C.J., Rha C., Sinskey A.J., Sudesh K. (2012) Biosynthesis and characterization of polyhydroxyalkanoate containing high 3-hydroxyhexanoate monomer fraction from crude palm kernel oil by recombinant $\mathrm{Cu}$ priavidus necator. Bioresource Technol. 121: 320-327.
Yakimov M.M., Timmis K.N., Golyshin P.N. (2007) Obligate oil-degrading marine bacteria. Curr. Opin. Biotech. 18: 257-266.

Yang F., Hanna M.A., Sun R. (2012) Value-added uses for crude glycerol a by-product of biodiesel production. Biotechnol. Biofuel. 5:13

Youssef N.H., Dunacn K.E., Nagle D.P., Savage K.N., Knapp R.M., McInerney M.J. (2004) Comparison of methods to detect biosurfactant production by diverse microorganism. J. Microbiol. Meth. 56: 339-347. 